\title{
KONTEKSTUALISASI PEMAHAMAN HADIS NABI TENTANG RIBA
}

\author{
Mohammad Nawir \\ Dosen Fakultas Syariah \\ mohammadnawirakib@gmail.com
}

\begin{abstract}
This study explores the issue of usury from the point of view of the hadith of the prophet. For the sake of finding supporting data against the argument that usury is not justified in Islamic law. This study uses a hadith science approach and various kinds of scientific approaches as supporters to understand the content of the hadith about usury. In this study, the authors found that before this study many criteria and benchmarks for usury were found in relation to buying and selling, exchanging, saving and borrowing, and knowing the laws of usury transactions clearly. Of course, studies on usury have been written by many Islamic law researchers, including Abdul Gofur with the theme of the concept of usury in the Koran, Riya Rohma Setyawati et al with the theme of usury in the view of Islam, Miriam So Phia with the theme of usury in Islamic jurisprudence, Abdurrahim Abdul Hamid al-sa'ati with the theme al-'illah al-Iqtishadiyah li tahrim al-Riba al-Nasiah wa alFadhl. Nevertheless, the author has its own uniqueness in examining the issue of usury in terms of the methods and approaches applied in this study. The approaches applied in this research include: First, the author uses a hadith science approach in conducting research, in order to be able to explore and explore the context of the prophet's hadith accurately. Second, the author uses various scientific approaches that can be a sharp tool in realizing an objective research.
\end{abstract}

Keywords: Contextualization; Hadith; Riba.

\begin{abstract}
Abstrak
Penelitian ini mendalami persoalan riba dari sudut pandangan hadis nabi. Demi ditemukannya data penguat terhadap argumen riba itu tidak dibenarkan dalam syariat Islam. Kajian ini menggunakan pendekatan ilmu hadis dan erbagai macam pendekatan ilmia sebagai pendukung untuk memahami kandungan hadis tetang riba. Pada penelitian ini penulis menemukan bahwa sebelum penelitian ini telah banyak ditemukan kriteria dan tolak ukur riba dalam kaitannya dengan jual beli, tukar-menukar, simpan pinjam, serta mengetahui hukum transaksi riba secara terang. Tentu saja kajian tentang riba telah banyak ditulis oleh para penelisik hukum Islam di antaranya Abdul Gofur dengan tema Konsep Riba dalam al-Quran, Riya Rohma Setyawati dkk dengan tema Riba dalam pandangan Islam, Miriam So Phia dengan tema Riba In Islamic Jurisprudence, Abdurrahim abdul hamid al-sa'ati dengan tema al-'illah al-Igtishadiyah li tahrim al-Riba al-Nasiah wa al-Fadhl. Kendatipun demikian, penulis memiliki keunikan tersendiri dalam mengkaji persoalan riba dari segi metode dan pendekatan yang diterapkan dalam penelitian ini. Pendekatan yang diterapkan dalam penelitian ini di antaranya Pertama, penulis menggunakan pendekatan ilmu hadis dalam melakukan penelitian, agar dapat menelusuri dan mendalami konteks hadis nabi secara akurat. Kedua, penulis menggunakan berbagai pendekatan ilmia yang dapat menjadi alat yang tajam dalam mewujudkan sebuah penelitian yang objektif.
\end{abstract}

Kata Kunci: Kontekstualisasi; Hadis; Riba.

TADAYUN:

Jurnal Hukum Ekonomi Syariah

Vol.2 No.2, Juli-Desember 2021 | 101

E-ISSN: 2774-4914 


\section{A. PENDAHULUAN}

Ajaran agama Islam berasal dari beberapa sumber yang turun temurun diyakini dengan penuh kepercayaan terhadap dalil agama yang ada sampai sekarang adalah wahyu ilahi yang telah diturunkan oleh Allah melalui malaikat jibril kepada nabi Muhammad, al-Quran dan hadis nabi merupakan sumber utama. Hadis nabi memiliki peran yang sangat fital di alam menentukan syariat agama Islam (tatanan hukum di dalam Islam) ${ }^{1}$ sehinggah dibutuhkan pemahman yang mendalam terkait hadis nabi, paling tidak sebelum mempelajari matan hadis terlebih dahulu mendalami rangkain ilmu-ilmu hadis.

Aktivitas Ekonomi pada kehidupan seorang manusia merupakan suatu keniscayaan yang tidak dapat dipungkiri kebermanfaatannya. Kegiatannya membantu guna memperoleh penghasilan, dan dengan penghasilan yang diperoleh ia dapat melangsungkan kehidupanya. Bagi orang Islam, pedoman dalam melakukan setiap aktivitasnya diperoleh dari al-Quran yang berkebenaran absolut. Sedang, Sunnah Rasulullah saw. berfungsi menjelaskan kandungan al-Quran. Terdapat banyak ayat Al-Quran dan hadis nabi yang merangsang manusia untuk melakukan aktivitas ekonomi salah satunya bekerja dengan rajin dan mencela orang menjadi pemalas. Tetapi tidak setiap kegiatan ekonomi itu punya watak yang merugikan banyak orang dan menguntungkan sebagian kecil orang, seperti monopoli dagang, calo, perjudian, dan riba, pasti akan di tolak. ${ }^{2}$

Hadis nabi membahas seluruh aspek kehidupan manusia termasuk persoalan riba, persoalan ini secara historis sudah sejak lama hidup dan berkembang dalam tatanan perekonomian manusia, sampai-sampai sudah hampir menjadi kebisaan buruk yang lumrah. Kendatipun demikian, kebiasaan tersebut tidak pernah ada satu agamapun yg melegalkan praktek-praktek ribawi. Terlebih dalam hal ini ajaran agama Islam, yang dengan tegas berulang-ulang menyinggung

\footnotetext{
${ }^{1}$ M Nawir, "Rekonstruksi Pemahaman Hadis Analisis Hadis Di Dalam Fatwa MUI Tentang Kesetaraan Jender," Journal of Qur'an and Hadith Studies 5, no. 2 (2016): 199-224, https://doi.org/10.15408/quhas.v5i2.13426.

${ }^{2}$ Muh Zuhri, Riba Dalam Al Qur'an Dan Masalah Perbankan: (Sebuah Tilikan Antisipatif) (Jakarta: PT. RajaGrafindo Persada, 1997), 1.
} 
persoalan keharaman riba secara teks. Namun tidak serta-merta seluruh pernyataan teks agama tersebut tentang keharaman riba langsung dilegal formalkan keharamannya kecuali setelah melalui banyak pendekatan terkait dengan pedekatan ekonomi. ${ }^{3}$

Persoalan riba, termasuk salah satu permasalahan yang sangat kompleks dalam kehidupan sehari-hari manusia, bahkan dalam pembahasan teks-teks keagamaan. Oleh sebab itu penelitian ini akan mengkaji secara mendalam terkait beberapa masalah yang muncul, dan akan dikaji dari beberapa sumber-sumber kitab hadi, tafsir, dan kitab-kitab fikih. Sehingga diharapkan akan menemukan sebuah kajian terbaru dalam hal rekonstruksi hukum dalam persoalan praktek riba. Meskipun tidak dapat dipungkiri bahwa penelitian yang rekonstruktif terkait dengan kebijakan hukum akan menuai kontroversi yang tajam kendatipun demikian konsekuensinya, mesti penelitian tetap berjan demi terwujudnya klaim hukum yang objektif.

Istilah Riba, sebagaimana yang tergambar dalam al-Quran bahwa riba itu sangat mirip dengan istilah jual beli hanya saja riba itu diharamkan sedangkan jual beli itu sendiri dihalalkan. Sehingga tidak heran jika terjadi dinamika pemaknaan atau penafsiran terkait dengan riba dan pelakunya. Keberadaan teks dalil agama dihadapkan dengan polemik prekonomian saat ini yang berbeda situasi dan kondisinya pada masa keluarnya teks agama (masa nabi dan sahabat). Di sini mulai tampak bahwa permasalahan riba sangat menarik untuk dibahas kembali, sekalipun sudah banyak penulis yang telah melakukan penelitian terkait dengan kasus yang akan dibahas, tentunya dengan bentuk tolak ukur dan pendekatan yang berdialektika. Mereka yang pernah menulis tentang riba di antaranya, Abdul Gofur dengan tema Konsep Riba dalam al-Quran, Riya Rohma Setyawati dkk dengan tema Riba dalam pandangan Islam, Miriam So Phia dengan tema Riba In Islamic Jurisprudence, Abdurrahim abdul hamid al-sa'ati dengan tema al-'illah al-Iqtishadiyah

\footnotetext{
${ }^{3}$ Muhammad Tho'in, “Larangan Riba Dalam Teks Dan Konteks (Studi Atas Hadits Riwayat Muslim Tentang Pelaknatan Riba)," Ilmiah Ekonomi Islam 2, no. 2 (2016): 64, https://doi.org/10.29040/jiei.v2i02.44.
} 
li tahrim al-Riba al-Nasiah wa al-Fadhl. tulisan-tulisan tersebut telah banyak membahas tentang riba, baik dari segi sejarah maupun dari segi prektek-praktek riba. Namun berbeda denga yang akan penulis tawarkan dalam penelitian ini. Pertama, penulis menggunakan pendekatan ilmu hadis dalam melakukan penelitian. Kedua, penulis menggunakan berbagai pendekatan yang dapat menjadi penopang terwujudnya sebuah penelitian yang objektif.

Terdapat beberapa permasalahan terkait riba yang sering menjadi polemik, khususnya di kalangan intelektual muslim di antaranya tolak ukur riba, kiasankisan hadis nabi terkait riba, persaman dan perbedaan riba dengan transaksi jual beli dll.

\section{B. PEMBAHASAN}

\section{Definisi Riba}

Riba meurut bahasa berasal dari bahasa arab yaitu dari pecahan kata rabayarbu, rabwan yang berarti az-ziyadah (tambahan) atau al-fadl (kelebihan). Di dalam al-Quran disebutkan pertumbuhan, peningkatan, bertambah, meningkat, menjadi besar, dan besar. juga sering diterapkan dalam pemaknan tanda kecil. Makna riba secara umum ialah meningkat terkait kualitas begitupun kuantitas. Sedangkan dari segi terminologi, riba ialah adanya bentuk tindakan peningkatan dari harta pokok atau modal secara batil. Riba juga dapat diartikan mengambil harta orang lain tanpa diikuti dengan jerih payah dan kemungkinan memperoleh resiko, memperoleh harta benda bukan dari imbalan kerja ataupun jasa, menarik perhatian dari orang-orang berduit dengan mesia-siakan kaum lemah, kemudian menafikankan sisi kemanusiaan demi menmperoleh materi. Kaitan riba dan albatil, di dalam kitab ahkam al-quran karangan Ibnu al-Arabi al-Maliki menjelaskan makna riba dari segi bahasa ialah tambahan. Akan tetapi riba sebagaimana disebutkan di dalam al-Quran, yaitu semua bentuk penambahan yang diperoleh tanpa adanya maksud pengganti atau penyeimbang yang di dapat banarkan oleh yari'ah.

Selain itu bunga bank bisa dimaknai sebagai bentuk balas jasa dari pihak 
bank dengan prinsip konvensional kepada nasabahnya. Bunga bank juga memungkinkan untuk dimaknai sebagai harta yang mesti diberikan kepada nasabah (yang memiliki simpanan) dan harga yang mesti diberikan nasabah kepada pihak bank (nasabah) yang memperoleh pinjaman. ${ }^{4}$

Tentu saja telah ditemukan beberapa bangsa dan Negara yang telah menyoroti aktifitas riba, namun tidak sedikit dari bangsa-bangsa tersebut telah ditimpah akibat dari azab atau lakat Allah baik berbentuk peperangan besar, maupun bencana alam. Andaikan akad secara riba ini dibenarkan, tentu saja tidak dibutuhkan lagi istilah di dalam agama konsep tolong menolong dan melindungi hak sesama manusia terlebih lagi atara yang kuat dan yang lemah. ${ }^{5}$ Demkian itu memungkinkan untuk dimaknai bahwa pengertian riba bukan termasuk jenis pertolongan yang benar-benar tulus dan ikhlas melainkan mengambil keuntungan dibalik kesulitan orang lain. Hal ini lah yang tidak dibolehkan oleh agama sebab apabila seluruh manusia meminta bunga dari uang, dampaknya mereka akan menjadi tidak bergairah untuk bekerja, wajar saja bila mereka akan merasa jauh lebih baik duduk berleha-leha dengan pandangan bahwa kelakuannya yang demikian pun tetap saja memperoleh keuntungan. Jika yang demikian itu terjadi maka boleh dikata bahwa riba itu menjadi salah satu penyebab merosotnya etos kerja manusia dan pada akhirnya membahayakan bagi ummat manusia. ${ }^{6}$

Kelompok lain berargumen melalui QS. Ali Imran [3]: 130. Dalam ayat tersebut, Allah SWT secara tersurat menyebutkan:

Terjemahannya:

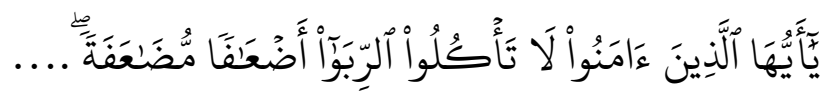

'Wahai orang-orang yang beriman, janganlah kalian memakan riba yang berlipat ganda...'

\footnotetext{
${ }^{5}$ A. Wangsawidjaja Z., Pembiayaan Bank Syariah (Jakarta: PT. Gramedia Pustaka Utama, 2012), 15.

${ }^{6}$ Asmawi, Filsafat Hukum Islam (Yogyakarta: PT. Teras, 2009), 99.
} 167.

${ }^{4}$ Syekh Samsuddin Abu Abdullah, Terjemah Fath Al-Qarib (Surabaya: Tim Cm Grafika, 2010), 
Lafaz ayat tersebut ditemukan kata adh'afan-mudha'afan, sebagian mengartikan sebuah syarat, dan penempatan kata tersebut merupakan sebuah syarat. Maka semakin menjadi terang bahwa suatu penambahan berbentuk kecil itu tidak tergolong pada kategori riba yang dikecam pada ayat di atas. Akan tetapi, pandangan ini tidak mendapatkan dukungan oleh sebagian besar ulama tafsir.? sebab di lingkungan ahli lugho, adh'afan-mudha'afan itu didudukkan sebagai sesuatu. Jadi dengan sendirinya hal yang berlipat ganda layaknya hanya keterangan situasi yang pernah diterapkan.

Perbedaan tersebut kemudian hari akan berdampak pada penafsiran ulama atas ketentuan riba. ${ }^{8}$ manakala riba dimaknai al-'Uluw, akibatnya dalam pemaknaan bahasa menjadi penambahan tidak hanya penambahan biasa. Namun harus mengandung sifat yang "tinggi", sebab 'uluw ialah lawan kata dari al-Suflu berarti mengandung makna paling bawah. ${ }^{9}$ Boleh jadi inilah yang kemudian berdampak pada pemaknaan Yusuf $\mathrm{Ali}^{10}$ dan Muhamad Asad ${ }^{11}$ pada saat memberikan istilah riba sebagai hal tidak wajar/berlebihan, pemerasan ${ }^{12}$ dan bukan kesejahteraan, manfaat, keuntungan bunga yang rendah/wajar.

Melalui banyaknya pendapat terkati dengan pandangan Riba, dapat ditarik kesimpulan, bahwasanya bukan hanya sekedar tambahan yang berlipat ganda termasuk kedalam kategori riba atau usury. Pemaknaan al-'Uluw dipakai pada setiap kelebihan dari perolehan seharusnya yang juga biasa dikenal dengan bunga atau interest. Dapat dikatakan pengambilan keuntungan atau hanya memperoleh manfaat dari suatu pinjaman maka dikategorikan sebagai riba yang dihukumi

\footnotetext{
${ }^{7}$ Al-Husain bin Muhammad Ar-Raghib al- Asfahaniy, Tafsir Ar-Raghib Al-Asfahaniy (Riyadh: Dar al-Wathan, 2003), 852.

${ }^{8}$ Muhammad bin Mukrim bin Mundzir al-Afriqiy Al-Masriy, Lisan Al-Arab (Beirut: Darr $₫ a d r$, n.d.). Diikuti pula oleh Majma' (Dewan) Lugoh 'Arabiyyah, Mu’jam Al-Wasith. (kairo: Dar ad-Da’wah), 326. 1987), 950.

${ }^{9}$ Ibnu Duraid, Jamharatul Al-Lughah, Edition by Ramzi Munir (Beirut: Dar 'Ilm lil Malayin,

${ }^{10}$ Ali Yusuf, The Holy Qur-an: English Translation of The Meanings and Commentary (Riyadh: King Fahd Holy Quran Printing Complex, n.d.), 126.

${ }^{11}$ Muhammad Asad, The Message Of The Quran; Translated And Explained, n.d., 847-48.

${ }^{12}$ Philip D Morehead, The New American Webster Dictionary, 4th ed., 2001, 853.
} 
haram. Pemaknaan tersebut diperkuat dengan penjelasan dalam QS. Al- Baqarah [2]: 279, fa lakum ru'usu amwalikum, yang layak untuk diterima oleh pemberi pinjaman hanyalah pokok utangnya. Lalu dengan penutup ayat tersebut, la tadzlimun wa la tudzlamun (janganlah kamu menganiaya dan tidak pula menjadi yang dianiaya), telah menetapkan setiap tindakan tersebut adalah sebuah kedzaliman, dan haram untuk dipertahankan oleh ummat Islam.

\section{Term Riba di Luar Agama Islam}

Sejatinya term riba telah familiar dalam transaksi-transaksi perekonomian pada masyarakat Arab sebelum datangnya Islam. Namun, pada masa itu riba yang berlaku merupakan tambahan dalam bentuk uang akibat penundaan pelunasan hutang. Dengan demikian, riba dapat diartikan sebagai pengambilan tambahan dalam transaksi jual beli maupun hutang piutang secara batil atau bertentangan dengan ketentuan Allah. Bahkan istilah riba tidak selamanya identik dengan Islam, karena pada ajaran agama lain juga telah mengenal riba dan tidak membenarkan atas perbuatan riba, bahkan sejarah berkata bahwa peraturan konstitusi, sosial, dan keagamaan telah ada sejak sebelum agama Islam datang.

Bangsa Yunani kuno telah dikenal sebagai pemilik dan pengusung peradaban tinggi, dengan demikian mereka memegang bahwa peminjaman uang dengan memungut bunga dilarang keras. Hal tersebut tergambar pada beberapa pernyataan Aristoteles yang sangat mengecam para pemuja uang yang gemar membungakannya. ${ }^{13}$ Bahkan kerajaan Romawi sebagaimana tercatat dalam historisitas bahwa kerajaan yang pertama kali menetapkan undang-undang terkait penegasan terhadap pelaku rentenir yang senang meminta bunga dari uang. Agama Yahudi dan Nasrani juga tertulis secara lugas di dalam kitab mereka bahwa perilaku riba atau pembengkakan terhadap bunga uang sangat tidak dibenarkan, kendatipun keduanya sedikit berbeda dalam penerapannya.

${ }^{13}$ Pusat Pengembangan Islam, Buku Pintar BMT Unit Simpan Pinjam Dan Grosir (Surabaya, n.d.), 


\section{Pembahasan Riba dalam al-Quran}

Surah ar-Rum [30]: 39, yang berbunyi:

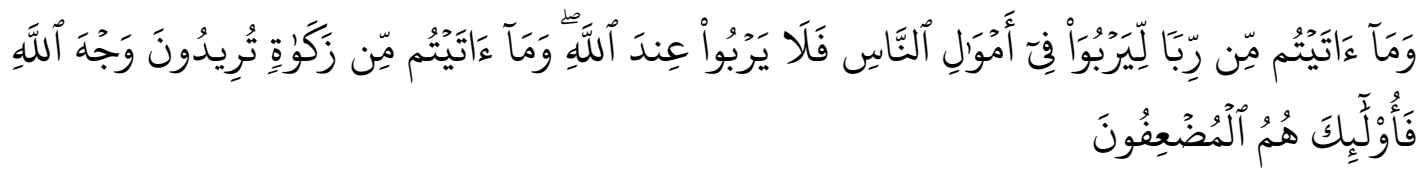

Terjemahannya:

'Dan sesuatu riba (tambahan) yang kamu berikan agar dia bertambah pada harta manusia, maka riba itu tidak menambah pada sisi Allah.'

Surah an-Nisa [4]: 161, yang berbunyi:

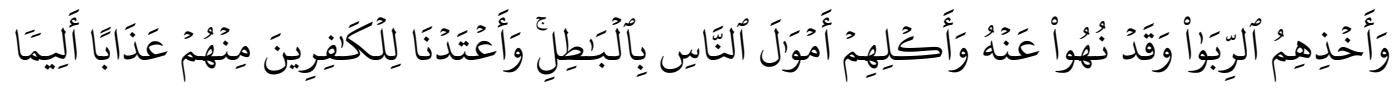

Terjemahannya:

'Dan disebabkan mereka memakan riba, padahal sesungguhnya mereka telah dilarang daripadanya.'

Surah Al-Imran [3]: 130, yang berbunyi:

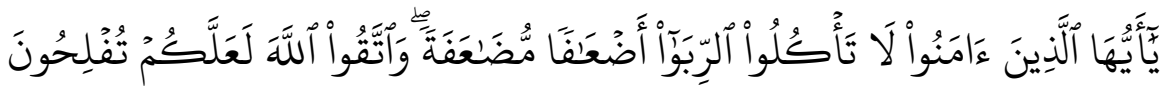

Terjemahannya:

'Hai orang-orang yang beriman, janganlah kamu memakan riba dengan berlipat ganda.'

Surah al-Baqarah [2]: 275, yang berbunyi:

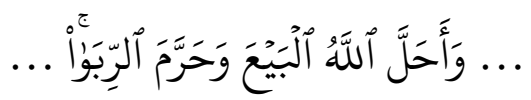

Terjemahannya:

'Dan Allah telah menghalalkan jual-beli dan mengharamkan riba.'

\section{Pembagian Riba}

a. Riba Qardh

Manfaat atau tingkat kelebihan tertentu yang disyaratkan terhadap yang berutang (muqtaridh).

b. Riba Jahiliyah

Suatu keuntungan dibayar lebih dari pokoknya karena si peminjam tidak 
mampu membayar utangnya pada waktu yang di tetapkan. Dari segi penundaan waktu penyerahanya, riba jahiliyah tergolong riba nasiah, sedangkan dari segi kesamaan objek yang dipertukarkan tergolong riba fadhl.

c. Riba Fadhl

Riba semacam ini juga dapat disebut riba buyu yaitu riba yang timbul akibat pertukaran barang sejenis yang tidak memenuhi kriteria sama kualitasnya ( (بثثل), sama kwantitasnya (سواء بسواء) dan sama waktu penyerahanya (بياء).

d. Riba Nasiah

Riba nasiah terkadang diistilahkan dengan riba duyun yaitu riba yang tampak akibat utang piutang yang tidak memenuhi kriteria untung muncul bersama resiko (لغنم بالغم) dan hasil usaha muncul bersama biaya (خرج بضن).

Diskursus seputar riba juga digunakan dua istilah riba dayn dan riba bay', tentunya dari kedua istilah tersebut terdapat perbedaan. Adapun yang menjadikan riba dayn dan bay' berbeda ialah faktor ditemukannya betuk barang yang telah ditetapkan pada batasan jenis riba bay'. adapun untuk jenis riba dayn, tidak terdapat secuilpun batasan, dengan syarat si pemberi pinjaman memperoleh manfaat, yang besar atau kecil, dari si peminjam, karena itu menjadi dikelompokkan dalam bentuk riba yang tidak dibenarkan. demikianlah yang telah diringkas oleh sebagian besar Ulama.

\section{Literatur Hadis Tentang Riba}

Dapat dikatakan titik persoalan terbesar dalam persoalan riba terletak pada penjelasan kitab-kitab fikih. Sedangkan literatur hadis sendiri, persoalan pokoknya ditemukan tiga persoalan. Dari tiga persoalan itu sebebetulnya merujuk pada pemahaman sahabat nabi, yang telah tertera pada kitab-kitab atsar nabi, berupa penjelasan maupun kandungan hadis. tiga persoalan itu ialah: 1. Pengelompokan riba dayn, 2. Perbedaan pandangan di kalangan sahabat terkait riba, 3. Belum terperincinya persoalan riba pada masa Nabi.

Ulama hadis dari masa ke masa telah banyak membahas dan meneusuri hadis nabi terkait riba, sebut saja di antaranya Imam al-Khatthabi, Ibn Mulaqqin, 
Ibn Baththal, at-Thibi, Ibn Rajab, dan al-'Aini, Ibnu hajar dan as-Shan'ani. Dan terdapat di antara beberapa persilangan pendapat terkait jeni dan ketentuan secara terperinci tentantang riba.

Penulis berupaya menelusuri literatur hadis terkait riba dan problematikanya, sehingga penulis menemukan butir-butir hadis sebagai berikut:

$$
\begin{aligned}
& \text { عن سعيد بن أبى بردة ,عن أبيه قال :أتيت المدينة فلقيت عبد الله بن سلام رضى الله عنه فقال: } \\
& \text { ألا تبىء فأطعمك سويقا وتمرا وتدخل فى بيت, ثم قال :إنك بأرض الربا بها فاش إذا كان لك على } \\
& \text { رجل حق فأهدى إليك حمل تبن. أو حمل شعير, أو حمل قت فلا تأخذه فإنه ربا }
\end{aligned}
$$

Artinya:

'Aku (Abu Burdah) mengunjungi Madinah lalu bertemu dengan 'Abdullah bin Salam ra. Aku berkata, "Tidakkah sebaiknya engkau berkunjung ke rumahku, nanti kusuguhi makanan terbuat dari tepung dan kurma, dan kamu masuk ke dalam rumah." Kemudian dia ("Abdullah bin Salam) berkata, "Sungguh kamu sekarang berada di negeri dengan praktek riba sudah merajalela. Jika kamu bersama seseorang yang bisa dipercaya, kemudian ia menghadiahkan kepadamu buah tin, gandum atau biji-bijian, maka janganlah kamu mengambilnya karena itu adalah riba". ${ }^{14}$

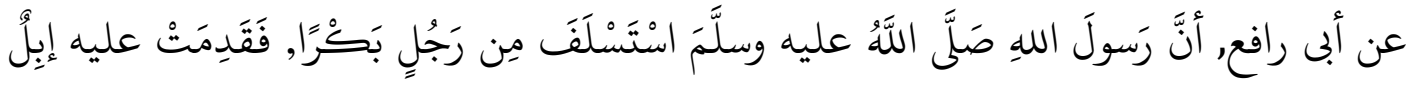

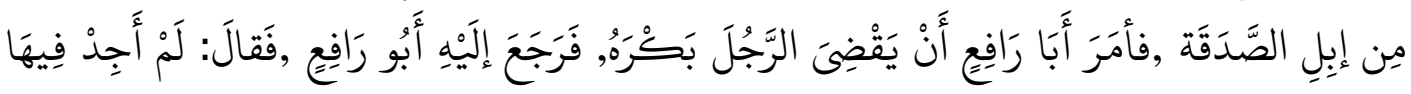

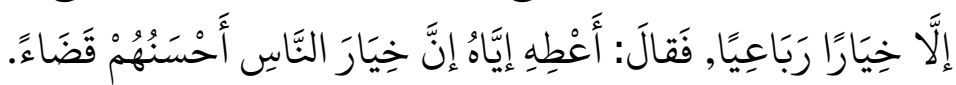

Artinya:

'Dari Abu Rafi', bahwa Rasulullah SAW pernah meminjam unta muda dari seorang laki-laki, ketika unta sedekah tiba, maka beliau pun memerintahkan Abu Rafi' untuk membayar unta muda yang dipinjamnya kepada laki-laki tersebut. Lalu Abu Rafi' kembali kepada beliau seraya berkata, "Aku tidak mendapatkan unta muda kecuali unta yang sudah dewasa." Beliau bersabda: "Berikanlah kepadanya, sebaikbaik manusia adalah yang paling baik dalam membayar hutang." 15

\footnotetext{
${ }^{14} \mathrm{Abu}$ 'Abdullah Muhammad bin Isma'il Al-Bukhari, Al-Jami' Al-Sahih, Ed. by Musthafa Dib, (Beirut: Darr Ibnu Katsir, 1987), 38.

15 Muslim bin al-Hajjaj Abu al-Husain al-Qusyairiy Al-Naisaburiy, Shohih Muslim, by Muhammad Fuad Abdul Baqiy (Darr Ihya al-Turats al-Arabiy, n.d.), 1224.
} 


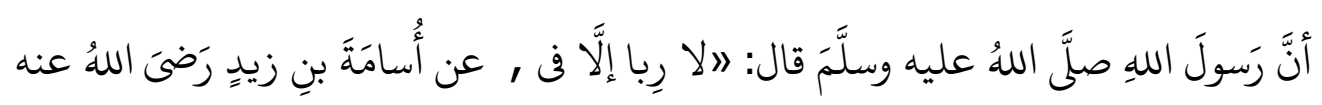

Artinya:

'Dari Usamah bin Zaid, bahwasanya ia pernah mendengar Rasulullah saw. bersabda, "Tidak ada riba, kecuali riba nasiah (pada penangguhan)."

Hadis lainnya menjelaskan:

$$
\text { الديتار بادينار وادرهم بادرهم لا زيادة }
$$

Artinya:

'(Utang satu) Dinar dibayar (satu) dinar, (satu) dirham dibayar (satu) dirham, tidak ada tambahan padanya.'

Setelah ditelusuri berbagai riwayat terkait riba, akhirnya ditemukanlah bahwasanya Rasulullah saw. memang tidak sempat merinci praktek apa saja yang termasuk pada riba, secara utuh. Keterangan tersebut dikisahkan oleh Umar bin Khatthab. Seperti dalam riwayat bahwa Umar pernah berkata, Sungguh di antara dalil-dalil diwahyukan Allah yang paling akhir ialah dalil tentang riba. Dan nabi muhammad telah wafat, belum memberikan penjelasannnya. Karena itu jauhilah dari kalian bentuk riba dan segala sesuatul yang meragukan.

Salah satu literatur hadis yang sampai di tangan kita saat ini yaitu Sunan Ibn Majah, terdapat di dalamnya penjelasan terkait dengan penyampaian Umar bahwa nabi belum memberikan penafsiran, ibnu majah mengatakan yang dimaksud dengan stetmen tersebut ialah penafsiran secara utuh, dengan rincian bagianbagian terkecil, dengan demikian ummat ini tidak perlu repot melakukan qiyas. Argumen bahwa riba adalah tergolong hukumnya haram, tidak dapat dipungkiri. Ketidak sesuaiannya pun telah dirasakan oleh berbagai lingkup agama bahkan peradaban manusia. Akan tetapi pada saat masuk dalam dalam ruang perincian, maka tentu hal tersebut dengan sendirinya terjadi khilaf di dalamnya. Tentu sesuatu yang wajar, karena hal tersebut merupakan ranah ijtihad, yang tidak datang nash qath'i tentangnya. Dengan kata lain, ummat sebaiknya mencermati betul perkataan Umar, Maka hindarilah dari kalian perbuatan riba dan segala sesuatu 
yang bersifat meragukan (terindikasi riba padanya; sebagai bentuk dari kehati-hatian seorang mukmin).

\section{Argumentasi Hadis Riba}

Ahmad Musthafa al-Maragi mewakili dari kalangan ulama kontemporer, dalam tafsirnya menyatakan bahwa ada dua bentuk riba dalam hukum Islam. Di antaranya ialah, riba al-qardh yang berhubungan dengan tambahan atas pinjaman, dan yang berhubungan dengan tambahan atas jual-beli dinamai riba al-buyu. Riba al-fadhl dan riba al-nasiah merupakan pembagian dari riba al-buyu. ${ }^{16}$ Sedangkan dalam pandangan Ibnu Hajar bahwa segala bentuk jual beli yang hukumnya haram itu masuk dalam kategori riba. ${ }^{17}$ Taqiy al-Dīn menjelaskan dalam karyanya Kifayah al-Akhyar bahwa riba al-fadhl, ialah cakupan barang yang ditukar dalam waktu yang bersamaan dengan kualitas dan kuantias yang berbeda. Adapun riba nasi'ah, terdiri dari segala bentuk aktifitas penukaran dalam kurun waktu yang bersamaan pelaksanaannya, keduanya tidak dibenarkan. ${ }^{18}$ terkait riba al-fadhl, kalangan ulama menafsirkannya pun dengan beragam. sebagian mengharamkan, dan sebagian membolehkan. ${ }^{19}$ Namun sebagian besar ulama kontemporer membolehkan riba al-fadhl dengan argumentasi maslahat atau kebutuhan. Sedagkan yang diharamkan adalah riba yang berlipat-lipat keuntungannya. ${ }^{20}$

Mahmud Syaltut dan Muhammad Abduh, secara jelas menegaskan bahwa yang haram hanya riba yang menuai keuntungan yang berlipat-lipat. Pada kalangan Ulama semisal Thaba'tabai dalam tafsir al-Mizan menyatakan bahwa riba terdiri atas dua, yaitu riba qardhiy yang berkaitan dengan pinjaman, dan riba

\footnotetext{
${ }^{16}$ Ahmad Musthafa Al-Maragiy, Tafsir Al-Maragiy, Juz II (Mesir: Musthafa al-Babi al-Halabi wa Awladuh, 1979), 211.

${ }^{17}$ Abdul Wahab Khallaf, Ilmu Ushul Fighi (Mesir: Maktabah al-Dakwah al-Islamiyah Syu'bah al-Azhar, 1957), 217.

${ }^{18}$ Taqiy al-Dīn Abī Bakar bin Muhammad al-Husainiy, al-Hushniy alDimasyqy al-Syafī’iy, Kifāyah al-Akhyār fī Hal Gāāyah al-Ikhtishā, juz I, (t.t.: Syirkah al-Ma'ārif li al-Thba' wa al-nasyr, t.th), 247.

${ }^{19}$ Muhammad al-Jaziriy, Kitab Fiqh Ala Mazahib Al-Arba'ah, Juz II (Beirut: Dar al-Fikr, 1982), 246.

${ }^{20}$ Chuzaimah T. dan Hafiz Anshary Yanggo, Problematika Hukum Islam Kontemporer (Jakarta: LSIK, 1999), 39 dan 41.
} 
mu'āmalah yang berkaitan dengan transaksi, yang disebutkan pertama ialah seorang melakukan peminjaman sejumlah barang atau uang terhadap pemberi pinjaman, lalu ia mengembalikannya dengan sesuatu yang lebih besar. Adapun yang disebut terakhir ialah persoalannya bukan masalah pinjaman, akan tetapi transaksi yang berlaku pada pertukaran antar jenis barang yang sama persis, contohnya gandum yang berkualitas baik dengan gandum yang kualitas buruk. ${ }^{21}$

Sebagian ahli fikih berpijak pada lafadz hadīs yang dimaksud, mereka berpandangan jenis riba itu tercakup dalam enam hal saja. Golongan Zahiriyyah berpegang pada pendapat ini, Qatadah, Thawus, Ibn Aqil al-Hanbali, dan Usman al-Batti. ${ }^{22}$ dampak dari pandangan ini ialah segala bentuk riba lainnya tidak dapat disebut sebagai riba. Abu Hanifah, dan Ahmad bin Hanbal, dalam suatu riwayat memandang bahwa segala sesuatu yang dijual dengan memakai takaran atau timbangan dapat disebut riba. ${ }^{23}$ Al-Syafii dan Ahmad dalam suatu riwayat berpendapat bahwa riba itu memasuki emas, perak dan tiap-tiap makanan dan minuman yang dijual dengan memakai ukuran tertentu. Mazhab Maliki memandang keharaman riba fadhl itu atas makanan yang merupakan makanan pokok yaitu makanan yang biasanya menguatkan badan. pendapat dari Taqiyuddin, bahwa riba tidak akan terjadi di dalam praktek jual beli dan salam, pada selain enam jenis barang yang disebutkan dalam hadis. adapun riba dalam praktek qard bisa terjadi pada seluruh bentuk, karena selain keenam jenis barang tersebut tidak terdapat satu dalil pun yang mengharamkannya, sehingga praktek riba tidak terjadi pada yang selainnya.

Syaikh Mahmud Syaltut mengemukakkan, bahwa masa sekarang bentuk uang ialah merupakan hajat manusia secara umum, uang yang ditabung oleh sipenyimpan misalnya di bank, tidak termasuk utang. Syaikh Mahmud Syaltut menartikan bahwa aktifitas tabung menabung merupakan pertukaran uang dalam

\footnotetext{
${ }^{21}$ Allamah Muhammad Husayn Thabathabaiy, Al Mizan Fi Tafsir Al-Quran, Jilid II (Teheran: Dar al-Kutub al-Ilmiyah, 1971), 293-94.

${ }^{22}$ Wahbah Zuhaili, Al-Figh Al Islamiyah Wa Adillatuh, Juz IV (Suriah: Dar al-Fikr, 1989), 636.

${ }^{23}$ Badruddin Abi Mahmud Muhammad bin Ahmad al-A'ini, Umdat Al-Qariy Syarh Syahih Bukhari (Beirut: Dar al-Fikr, n.d.), 252.
} 
bentuk perdagangan tidak sering terjadi saling merugikan dalam lingkup perdagangan. ketika menjelaskan tentang tabungan, ia sepertinya memfokuskankan perhatian pada munculnya keuntungan antara pemberi dan penerima, kendatipun bentuk akad yang dilakukan terjebak dalam kaidah riba jenis ribanasi'ah. Berkaitan dengan hukum riba, memungkinkan terbagi menjadi dua bagian. satu menghukumi riba dengan haram, jenis keuntungan bersifat besar atau bersifat kecil. Dua menghukumi riba haram ketika pada sesuatu yang digandakan. Penambahannya berbentuk kecil, menurut bagian kedua, demikian itu tidak tergolong riba yang tidak dibenarkan. Bentuk riba sebagaimana tersebut di atas lahir jika sipeminjam barang orang lain, apa pun bentuk barangnya, dapat dibebani dari si pemberi pinjaman untuk membayar suatu tambahan tertentu di samping pokok pinjaman pada saat penyelesaian. Apabila tambahan itu ditetapkan sebelumnya pada awal transaksi sebagai suatu jumlah tertentu, dengan menggunakan cara bagaimanapun pembengkakan ini terjadi, maka pinjaman tersebut berubah menjadi pinjaman yang tidak dibenarkan (riba).

Larangan menjadi melebar keseluruh dimensi pinjaman begitupun dengan utang berupa pemberian tambahan terhadap peminjam. Terkait yang telah jelaskan di atas, kaidah riba nasi'ah sebagaimana telah dikemukakan ulama sejatinya meliputii tiga macam. satu, terjadi sebab pemimjaman pada waktu sebagaimana telah disepakati ketentuannya. Dua, terhadap pelaku uatang atau peminjam diwajibkan mengembalikan tambahan terhaap pemberi layanan utang pada saat pengangsuran atau pelunasan, sesuai dengan ikatan perjanjian yang ada. Tiga, bentuk yang dipinjam sejenis benda yang dikelompokkan dalam hal riba. Di lain sisi pada aktifitas jual beli berbentuk aktifitas finansial sebgaimana yang berlaku di dunia secara global, medel jual beli sangat banyak didapati pada bank-bank yang bersifat asing, semisalnya tansaksi jual dan beli mata uang yang berbentuk rupiah dengan dolar inggris dll. Ini dapat dihukumi boleh, sebab mata uang tersebut bisa dikatakan terang menderang karena terdapat bukti transaksi yang telah dilakukan, pada akhirnya pemilihan terhadap objeknya dapat ditetapkan. 
Penulis di dalam penelitian ini cenderung searah dengan argumen dari tokoh terkemuka yaitu al-Sabunī ketika menjelaskan permasalahan riba. ia menekankan, bahwa terdapat beberapa persoalan yang kemudian menyebabkan riba menjadi haram, di antaranya ialah dapat membahayakan terhadap jiwa, memporak porandakan keutuhan ummat, dan mencerai-beraikan keharmonisan kemasyarakatan.

\section{KESIMPULAN}

Penelitian ini telah menemukan bahwa memang benar dalil agama telah mengakomodir keharaman riba termasuk hadis nabi, namun penjelasan tentang jenis prilaku secara rinci terkait riba secara teranag-terangan tidak ditemukan melainkan qiyasan-qiyasan dari para musyarrih hadis saja. Berikutnya keharaman riba, sebagai sebuah status hukum, tidak dapat dipungkiri dari berbagai macam aspek. Mulai dari aspek Keagamaan, Historisitas, dan humanitas seluruhnya mengakomodir bahwa riba merupakan perbuatan yang terlarang sejak dahulu sebelum datangnya Islam hingga literatur agama yang sampai di tangan kita saat ini. Ketidak sesuaiannya pun telah dirasakan oleh berbagai lingkup agama bahkan peradaban manusia. Akan tetapi pada saat masuk dalam dalam ruang perincian, maka tentu hal tersebut dengan sendirinya terjadi khilaf di dalamnya. Hal demikian tentu dapat diwajari, sebab hal demkian merupakan ruang lingkup ijtihad, yang tidak didapati nash qath'i terkait persoalan tersebut.

\section{REFERENSI}

Allamah Muhammad Husayn Thabathabaiy. (1971). al Mizan fi Tafsir al-Quran (Jilid II). Teheran: Dar al-Kutub al-Ilmiyah.

Asad, M. (n.d.). The Message Of The Quran; Translated And Explained.

Asmawi. (2009). Filsafat Hukum Islam. Yogyakarta: PT. Teras.

Badruddin Abi Mahmud Muhammad bin Ahmad al-A'ini. (n.d.). Umdat al-Qariy Syarh Syahih Bukhari. Beirut: Dar al-Fikr.

Al-Bukhari, A. 'Abdullah M. bin I. (1987). Al-Jami' Al-Sahih, ed. by Musthafa Dib (by Musthaf). Beirut: Darr Ibnu Katsir.

Duraid, I. (1987). Jamharatul al-Lughah (Ramzi Muni). Beirut: Dar 'Ilm lil Malayin. 
Al-Husain bin Muhammad Ar-Raghib al- Asfahaniy. (2003). Tafsir Ar-Raghib AlAsfahaniy. Riyadh: Dar al-Wathan.

Islam, P. P. (n.d.). Buku Pintar BMT Unit Simpan Pinjam dan Grosir. Surabaya.

Khallaf, A. W. (1957). Ilmu Ushul Fiqhi. Mesir: Maktabah al-Dakwah al-Islamiyah Syu'bah al-Azhar.

Al-Maragiy, A. M. (1979). Tafsir al-Maragiy (Juz II). Mesir: Musthafa al-Babi alHalabi wa Awladuh.

Al-Masriy, M. bin M. bin M. al-A. (n.d.). Lisan al-Arab. Beirut: Darr \$adr.

Morehead, P. D. (2001). The New American Webster Dictionary (4th ed.).

Muh Zuhri. (1997). Riba Dalam Al Qur'an Dan Masalah Perbankan : (Sebuah Tilikan Antisipatif). Jakarta: PT. RajaGrafindo Persada.

Muhammad al-Jaziriy. (1982). Kitab Fiqh ala Mazahib al-Arba'ah (Juz II). Beirut: Dar al-Fikr.

Al-Naisaburiy, M. bin al-H. A. al-H. al-Q. (n.d.). Shohih Muslim by Muhammad Fuad Abdul Baqiy. Darr Ihya al-Turats al-Arabiy.

Nawir, M. (2016). Rekonstruksi Pemahaman Hadis Analisis Hadis di dalam Fatwa MUI tentang Kesetaraan Jender. Journal of Qur'an and Hadith Studies, 5(2), 199-224. Retrieved from https://doi.org/10.15408/quhas.v5i2.13426

Syekh Samsuddin Abu Abdullah. (2010). Terjemah Fath al-Qarib. Surabaya: Tim Cm Grafika.

Taqiy al-Dīn Abī Bakar bin Muhammad al-Husainiy, al-Hushniy alDimasyqy alSyafīìy, Kifāyah al-Akhyār fī Hal Gāāyah al-Ikhtishā, juz I, (t.t.: Syirkah alMa'ārif li al-Thba' wa al-nasyr, t.th).

Tho'in, M. (2016). Larangan Riba Dalam Teks Dan Konteks (Studi Atas Hadits Riwayat Muslim Tentang Pelaknatan Riba). Ilmiah Ekonomi Islam, 2(2), 6372. https://doi.org/10.29040/jiei.v2i02.44.

Wangsawidjaja Z., A. (2012). Pembiayaan Bank Syariah. Jakarta: PT. Gramedia Pustaka Utama.

Yanggo, C. T. dan H. A. (1999). Problematika Hukum Islam Kontemporer. Jakarta: LSIK.

Yusuf, A. (n.d.). The Holy Qur-an: English Translation of The Meanings and Commentary. Riyadh: King Fahd Holy Quran Printing Complex.

Zuhaili, W. (1989). al-Fiqh al Islamiyah Wa Adillatuh (Juz IV). Suriah: Dar al-Fikr. 